SeCCión Historia Del DERECHO PATRIO CHILENO 

Revista de Estudios Histórico-Jurídicos

[Sección historia del derecho patrio chileno]

XL (Valparaíso, Chile, 2018)

[pp. 283 - 308]

\title{
"LA INCULTURA EN QUE ESPAÑA MANTENÍA A SUS COLONIAS", DOS TÓPICOS DEL MITO FUNDACIONAL Republicano en CHILE
}

["The Inculture in Which Spain Maintained its Colonies", Notes on the use of two Topics of the Republican Foundational Myth in Chile]

\author{
Eduardo ANDRADEs Rivas* \\ Universidad del Desarrollo, Concepción, Chile
}

\begin{abstract}
RESUMEN
El artículo examina un tópico clásico de la historiografía jurídica del siglo XIX, la afirmación de que la Monarquía Hispánica mantenía a los reinos americanos, sus supuestas colonias, en la ignorancia y el analfabetismo, impidiendo la difusión de libros, a fin de volverles dóciles y obedientes al absolutismo.

Se abordan las principales iniciativas culturales de la Monarquía en relación con la difusión de las letras entre sus vasallos americanos. Y se exponen los orígenes liberales del anacronismo c ol o n i a que Claudio Gay y sus contemporáneos y continuadores emplearon para denominar al periodo indiano.

Palabras clave

Colonia - Monarquía Hispánica Ignorancia - Educación - Bibliotecas Educación pública - Tiranía.
\end{abstract}

\begin{abstract}
This article examines a classic topic of XIX legal historiography, the assertion that the Hispanic Monarchy kept the American kingdoms, their "colonies", in ignorance and illiteracy, preventing the spreading of books, in order to make them docile and compliant to absolutism.

The main cultural initiatives of the Monarchy in relation to the dissemination of letters among their American vassals are addressed. Besides, the liberal origins of the c ol o n y anachronism, that Claude Gay and his contemporaries and followers used to describe the Indian period, are exposed.

Keywords

Colony - Hispanic Monarchy Ignorance-Education - Libraries - Public education - Tyranny.
\end{abstract}

RECIBIDO el 28 de noviembre de 2017 y ACEPTADO el 2 de julio de 2018

* Doctorando del programa de Doctorado en Derecho de la Facultad de Derecho de la Universidad Nacional de Educación a Distancia, Madrid, España. Profesor titular de Historia del Derecho de la Facultad de Derecho de la Universidad del Desarrollo (Concepción). Dirección postal: Ainavillo 456, 5 piso, Concepción, Chile. Correo electrónico: eandrade@udd.cl. 


\section{INTRODUCCIÓN}

Entre las muchas afirmaciones con las que se intentó explicar, en el siglo XIX, el proceso de la secesión chilena -y americana- de la Monarquía Hispánica, se encuentran las dos afirmaciones que dan título a este breve estudio y que siempre se presentan unidas.

Se trata de una de las más persistentes herencias de la historiografía liberal americana y chilena, la de las supuestas causas de la Revolución de Independencia o más bien, Secesión de los Reinos de América de la Corona Hispánica. Largos fueron los relatos con que los historiadores y juristas liberales pretendieron justificar el proceso de secesión. Puntos de vista historiográficos que hoy podríamos calificar, al menos, de parciales se impusieron en nuestra América del XIX como dogmas de fe cívica. Desde las his to rias de la pat ria que los liberales proclamaban como rigurosamente históricas y que principiaban precisamente con los sucesos de $1810^{1}$, tendiendo un conveniente manto de penumbra sobre los verdaderos acontecimientos históricos y jurídicos que le daban a nuestro mundo un complejo y vasto pasado de cuatro siglos de monarquía; pasando por explicaciones tan alucinadoras como la supuesta formación de castas opuestas y excluyentes, como si la sociedad indiana hubiese sido una copia de la India británica ${ }^{2}$, hasta los voluntarios o involuntarios errores o mistificaciones que afirmaban que la secesión Americana había sido una guerra entre peninsulares y americanos y no el verdadero enfrentamiento entre americanos o hermanos que realmente fue ${ }^{3}$.

Cuando decimos secesión y no independencia apuntamos a la naturaleza jurídica del movimiento juntista de 1810 y sus consecuencias ${ }^{4}$. Contrariamente a lo que sostuvo el mito fundacional, el proceso que llevó a la desintegración de la Monarquía Hispánica no fue una sucesión de i n d e p e n d e n c i a s, de dominios o posesiones que hubieran llegado a la madurez social y política, que dejaban atrás a su progenitor, sino una serie de guerras civiles que fueron despojando al cuerpo político plural y diverso, unido por un conjunto de lazos culturales, religiosos, lingüísticos y sociales y coronado por el monarca, de su integridad, hasta hacerlo

${ }^{1}$ El más destacado ejemplo de lo que decimos es la obra de LASTARRIA, José Victorino, Bosquejo histórico de la Constitución del Gobierno de Chile, durante el primer periodo de la revolución, desde 1810 a 1814 (Santiago de Chile, 1847), 222 pp.

${ }^{2} \mathrm{Al}$ respecto estimaba don Benjamín Vicuña Mackenna: "En general, una profunda separación de clases que hizo a la sociedad chilena la más pobre de América y la más aristocrática y altiva. Así, mientras la plebe no tenía ni siquiera derecho al trabajo, los ociosos nobles pasaban su vida haciendo y rehaciendo sus árboles genealógicos. Entre ellos, una distancia enorme, no sólo entre nobles y plebe, sino también en todas las gradaciones intermedias entre sî". Estas caricaturas, obviamente sin respaldo en los hechos históricos, eran abundantísimas en la segunda mitad del siglo XIX. Ver Vicuña Mackenna, Benjamín, Historia crítica y social de la ciudad de Santiago, 1541-1868 (Santiago de Chile, 1926), II, p. 440.

3 Sobre el concepto de secesión y de guerra civil americana, nos remitimos al clásico estudio del profesor Federico Suárez Verdeguer, El problema de la independencia de América, en el cual analiza la distinción entre revolución de independencia y secesión. Ver SuÁrEz Verdeguer, Federico, El problema de la independencia de América, en Anales de la Fundación Francisco Elías de Tejada, 12 (2006), pp. 47-57.

${ }^{4}$ Ver SuÁrez Verdeguer, Federico, cit. (n. 3), pp. 47 ss. 
colapsar. Esto hubo de ser así pues el proceso de constitución de la Monarquía Hispánica fue el resultado de una muy compleja evolución que constituyó reinos de una densidad política y social muchísimo más sólida que unas simples colonias ${ }^{5}$ alzadas contra su metrópoli.

De esa desintegración provocada por las guerras civiles, surgirían no solo los nuevos estados americanos, sino el estado de España en la Península, esa España en clave liberal de la que políticamente solo podemos hablar tras la ascensión al trono de Isabel II.

Las referidas explicaciones, interesadamente repetidas por razones políticas y también por la pasión que despertaba en los historiadores decimonónicos la proximidad del proceso de secesión, fueron acogidas sin el menor espíritu crítico en los libros de texto que se utilizaron por largos años en la educación primaria y secundaria, constituyéndose en un pesado velo de ignorancia que tardó mucho en rasgarse ${ }^{6}$. Es lo que denominamos el $\mathrm{m}$ i t o f u n d a c i o n a l de la república. Aunque debe reconocerse que, junto con difundir las ideas que darían forma a tal mito, los historiadores clásicos hicieron una importante labor de conservación de documentación y de testimonios de la época que nos interesa, aunque dicha conservación o publicación se realizaba sin que se agregara el más mínimo estudio historiográfico sobre los mismos. En el fondo se trata de una enorme cantera documental que hasta hoy ha permanecido casi sin estudiarse.

Solo en el siglo recién pasado, historiadores de la talla de Guillermo Feliú, José Toribio Medina, Francisco Antonio Encina, Fernando Campos Harriet y Jaime Eyzaguirre Gutiérrez, más el político y ensayista Alberto Edwards Vives lograron romper con el oscurantismo con el que se había teñido tan importante periodo de nuestra historia. Eyzaguirre bautizó a la leyenda liberal y a las explicaciones que se habían cristalizado sobre el proceso de secesión americana como "las causas ideológicas de la Independencia”. Conjuntamente con el esfuerzo por borrar el mito liberal anterior, esta nueva escuela de historiadores, con el mayor rigor y

${ }^{5}$ Ver Konetzke, Richard, América Latina, La época colonial (6a ed., traducción castellana de Pedro Scaron, México, 1977), pp. 34-49.

${ }^{6}$ En un interesante artículo, el doctor Javier Infante alude precisamente a este punto al sostener que: "Las pasiones que aún despertaba la guerra de Independencia, vivas aun cuando esta escuela estaba en su apogeo, distorsionó la visión que estos historiadores plasmaron en sus obras. La cercanía con los hechos objeto del estudio la encegueció ante la realidad. Su tratamiento muchas veces abiertamente parcial a favor de la causa de la Independencia, manifestado tanto en la aceptación de los argumentos que sustentaban aquella postura y la consecuente omisión o preterición de los argumentos en contra -sin siquiera mencionar el tratamiento que se daba a los principales personajes de uno u otro partido- son sin duda un defecto que resta valor a los trabajos de la época”. Infante consigna incluso un factor externo, pero de gran influencia sobre los historiadores clásicos: la guerra de Chile contra España en 1865-66, en la precisa época en que nuestros autores escribían sobre la independencia. De ahí que se enfatizaran todos los testimonios a n t i e s p a ñ o l e s. Ver Infante Martin, Javier Francisco Jesús, La historiografía constitucional en la formación nacional de Chile: 1810-1833, enfoques y discusiones, en Revista de Chilena de Derecho, 41/2 (2014), p. 749.

7 Ver EyZaguirre GutiérRez, Jaime, Ideario y ruta de la emancipación chilena (Santiago de Chile, 1957), 160 pp. 
la ecuanimidad emocional que les daba su lejanía temporal con los sucesos de la secesión, formularon explicaciones sobre el fenómeno que nos interesa.

No deja de ser irónico que, pese a esta vasta labor de revisión y estudio de las fuentes históricas, el mito ha continuado repitiéndose hasta nuestros días ${ }^{8}$.

En lo que nos ocupa, la historiografía liberal forjó dos mitos complementarios: el primero, el de una decisión deliberada de la Monarquía Hispánica de mantener a la población del continente americano en el analfabetismo y la ignorancia a fin de sujetar sus conciencias a un supuesto despotismo; y el segundo de los cuales, el de constituir los reinos de América simples colon i as, de las que extraer riquezas para costear los gastos de la metrópoli imperial, siendo los naturales de las primeras meros siervos a las órdenes de los señores peninsulares.

Ambas afirmaciones se han convertido en tópicos que todavía hoy son difíciles de desmontar.

\section{El oscurantismo cultural hispánico en Chile}

El primer mito sostiene que la Corona Hispánica se habría empeñado en negar a los españoles americanos los rudimentos básicos de la cultura, prefiriendo mantener a la población natural del Nuevo Mundo en un universal analfabetismo?. Así se evitaba la difusión de ideas que pudiesen alentar en la población los ideales de libertad política. Mientras más ignorante fuera la población, más esclava de

${ }^{8}$ Sobre el particular pueden consultarse los textos de estudio de historia nacional para la enseñanza secundaria: MendizÁBAl Cortés, María Antonieta; Riffo PastranA, Jorge, Texto del estudiante, Historia, Geografia y Ciencias Sociales, $2^{\circ}$ medio (Santiago de Chile, 2013), pp. 96 ss.; MÉndez Montero, Verónica et al., Guia Didáctica para el profesor, incluye texto para el estudiante, Historia, Geografia y Ciencias Sociales, $2^{\circ}$ educación media (Santiago de Chile, 2009), 144 pp.; y Santibáñez Galleguillos, Lucía; Muñoz Araya, Paola; Riffo Pastrana, Jorge, Guía didáctica del docente, Historia, Geografia y Ciencias Sociales, $2^{\circ}$ medio (Santiago de Chile, 2013), pp. 44 ss.

9 En 1812, fray Camilo Henríquez sostendría lo que con el tiempo cristalizaría en el mito fundacional sobre el punto: "La ignorancia entraba en el plan de la opresión. La educación fue abandonada: la estupidez, la insensibilidad ocuparon en los ánimos el lugar que se debía al sentimiento de su dignidad, al conocimiento de sus derechos: se corrompieron las costumbres, se adquirieron los vicios, y las inclinaciones de los esclavos; y acostumbrados los Pueblos a obedecer maquinalmente, creyeron que les era natural su suerte infeliz". Ver HenRíQuez, fray Camilo, Aurora de Chile [prospecto de febrero de 1812], en AURORA DE CHILE, disponible en: http://www.auroradechile.cl/newtenberg/681/article-11907.html. (23-03-2017). En el mismo sentido: "El gobierno español, al prohibir el comercio con las demás naciones, tuvo por objeto capital el aislar por completo á sus colonias de todo el resto del mundo. El poner obstáculos á la introducción de libros, era porque tenia miedo de que estos fueran un foco de luz que iluminase aquel eterno limbo en que estaba sumerjida esta raza tan digna de mejor suerte". Así lo afirma en 1894 el hagiógrafo de Martínez de Rozas, ver Martínez Lavín, Manuel, Biografia de Juan Martínez de Rozas (Santiago de Chile, 1894), pp. 76 ss. Aún en una fecha tan tardía como 1925, sostenía Luis Galdames, directamente influido por los historiadores clásicos: "Ni en Chile ni en ninguna otra de sus colonias estableció España un sistema docente: tampoco lo tuvo para ella misma”. Ver Galdames, Luis, Historia de Chile, la evolución constitucional (Santiago de Chile, 1925), p. 21. La influencia de este texto resulta de gran amplitud pues fue utilizado como material oficial de estudio en la educación pública chilena durante gran parte de la primera mitad del siglo XX. 
sus amos europeos. Evidentemente, una lectura desatenta del argumento podría resultar engañosa. En efecto, si la monarquía hubiese procurado mantener a los americanos en la ignorancia para dominar más fácilmente sus conciencias, no podría entenderse que la misma Corona se hubiere empeñado, a su costa, de fundar colegios, academias, centros de estudios y universidades a lo largo y ancho de todo el continente americano.

Mucho más fácil sería controlar la difusión del conocimiento sin impulsar una absurda política de educación general que abarcaba a los indígenas, incluido el caso del reino de Chile.

Los defensores de esta idea se preocuparon de resaltar la existencia del sistema de censura a la difusión de ciertas obras estimadas peligrosas para la Iglesia y la Corona. Sin embargo, se olvida que aún las obras más sujetas al reproche religioso o político podían ser adquiridas comprando una licencia que estaba al alcance de todo quien pudiera pagar la tasa por ella, y que permitió que gran parte de las obras oficialmente rechazadas fueran conocidas lícitamente en todo el continente.

En el caso de Chile estas obras fueron muy escasas, pero no se debió al sistema de censura sino a la doble circunstancia del analfabetismo casi universal de la población, como explicamos más adelante ${ }^{10}$, y al costo de los libros que resultaban prohibitivos para gran parte de los habitantes del país, el más pobre de los reinos americanos.

Incluso más, el negocio editorial en Chile, con varias imprentas introducidas en el reino ${ }^{11}$ antes de los sucesos de 1810, fracasó debido a los factores indicados: nadie compraba los libros impresos por ser muy caros y, además, porque eran muy escasos los posibles lectores ${ }^{12}$.

La falsedad de la supuesta política de impedir la educación pública tiene su

10 Vargas Cariola ha apuntado correctamente a que más del $90 \%$ de toda la población estaba en tal condición. Ver VARGas Cariola, Juan Eduardo, Las reacciones chilenas ante los sucesos de España, en Silva Vargas, Fernando; Vargas, Juan E., (eds.), 1808 1824, Historia de la república de Chile, el fin de la Monarquía y los orígenes de la república (Santiago de Chile, 2013), p. 181.

${ }^{11}$ La primera imprenta fue organizada en Chile por los padres de la Compañía de Jesús a mediados del siglo XVIII. Pero esta circunstancia histórica evidente fue ignorada por los promotores del mito fundacional. Dando forma a la fantasía don Claudio Gay sostendría que "Hasta entonces, Chile, sumergido en las espesas tinieblas del absolutismo y del abandono, no había podido elevarse a las altas regiones de la inteligencia, y estaba encharcado en el estado de nulidad que un gobierno egoísta le había impuesto". Ver GAY, Claudio, Historia física y política de Chile (Santiago de Chile, 2007), V, p. 95. Esta diatriba se complementaba indicando que la imprenta de don José Camilo Gallardo, creada en 1789, solo servía para editar esquelas y otros papeles menores. En abono de su tesis citaba el acuerdo de 21 de marzo de 1809 de la Universidad de San Felipe de mandar a comprar una imprenta en España o Buenos Aires. Pero todas estas afirmaciones chocan con la realidad: al menos existían dos completas imprentas en pleno funcionamiento en Chile, la de Gallardo y la de don José Vigil y Toro, el nieto del Conde de la Conquista, que dirigía el taller de la eximprenta de los jesuitas. Ver Soto Veragua, Jorge, Historia de la imprenta en Chile, desde el siglo XVIII al XXI (Santiago de Chile, 2009), pp. 47 ss.

12 Por el contrario, en el resto del continente el negocio editorial fue mucho más próspero, en México la primera imprenta fue establecida en 1535, a pocos años de la conquista, y por iniciativa del obispo fray Juan de Zumárraga. Otro tanto ocurrió en Lima en 1581, y fue en esta imprenta en donde el primer poeta español chileno, don Pedro de Oña editó su Arauco domado en 1596. Lo mismo que las gramáticas indígenas del padre Luis de Valdivia a inicios 
demostración más palmaria en las leyes de Indias. Allí es donde la Corona impulsó una vasta normativa que perseguía difundir la cultura a todos los rincones del continente ${ }^{13}$. Especial atención se puso en la fundación de colegios destinados a enseñar en ellos a los hijos de los indígenas, como fue el caso, en Chile, del famoso colegio franciscano de Propaganda Fide de Chillán, que sirvió de alma mater de los hijos de los caciques de Arauco y del joven Bernardo Riquelme, el hijo natural del virrey don Ambrosio O’Higgins y futuro líder secesionista.

Debe recalcarse que estas fundaciones eran patrocinadas y financiadas por la propia Corona, siendo la educación impartida, en la gran mayoría de los establecimientos, totalmente gratuita.

Bien sostuvo Lummis, en su clásico libro sobre los exploradores españoles del siglo XVI, en el que reivindica la acción civilizadora de la Monarquía Hispánica: "No solamente fueron los españoles los primeros conquistadores del Nuevo Mundo, y sus primeros colonizadores, sino también sus primeros civilizadores. Ellos construyeron las primeras ciudades, abrieron las primeras iglesias, escuelas y universidades; montaron las primeras imprentas y publicaron los primeros libros; escribieron los primeros diccionarios, historias y geografías, y trajeron los primeros misioneros; y antes de que en Nueva Inglaterra hubiese un verdadero periódico, ya ellos habían hecho un ensayo en México ¡y en el siglo XVII!”14.

del siglo XVII. Ver EyZAGuirre GuTIÉRreZ, Jaime, Historia de las Instituciones politicas y sociales de Chile (8a ed., Santiago de Chile, 1988), p. 39.

${ }^{13}$ De hecho, desde la fundación de Santiago de Chile, se crearon escuelas primarias para educar a los niños. La primera escuela de gramática latina, filosofía y retórica fue abierta en 1578 al amparo de la Catedral por el padre Juan Blas. Y solo la precariedad de la Real Hacienda, impidió fundar una universidad en el siglo XVI, pues en 1567 el obispo de Santiago de Chile, monseñor Juan Pérez de Espinoza y fray Antonio de San Miguel, ordinario de la diócesis de Imperial-Concepción, la habían solicitado. Ella se fundó finalmente en el siglo XVIII cuando las penurias económicas derivadas de la guerra de Arauco disminuyeron. Ver EyzAGUirRE GuTIÉRREZ, Jaime, Historia de las Instituciones, cit. (n. 12), pp. 39 ss.

${ }^{14}$ Prosigue en un párrafo que ha sido reproducido en numerosas obras posteriores: "Una de las cosas más asombrosas de los exploradores españoles -casi tan notable como la misma exploración- es el espíritu humanitario y progresivo que desde el principio hasta el fin caracterizó sus instituciones. Algunas historias que han perdurado pintan a esa heroica nación como cruel para los indios; pero la verdad es que la conducta de España en este particular debiera avergonzarnos. La legislación española referente a los indios de todas partes era incomparablemente más extensa, más comprensiva, más sistemática, y más humanitaria que la de la Gran Bretaña, la de las colonias y la de los Estados Unidos todas juntas. Aquellos primeros maestros enseñaron la lengua española y la religión cristiana a mil indígenas por cada uno de los que nosotros aleccionábamos en idioma y religión. Ha habido en América escuelas españolas para indios desde el año 1524. Allá por 1575 -casi un siglo antes de que hubiese una imprenta en la América inglesa- se habían impreso en la ciudad de México muchos libros en doce diferentes dialectos indios, siendo así que en nuestra historia solo podemos presentar la Biblia india de John Eliot; y tres universidades españolas tenían casi un siglo de existencia cuando se fundó la de Harvard. Sorprende por el número la proporción de hombres educados en colegios que había entre los exploradores; la inteligencia y el heroísmo corrían parejas en los comienzos de la colonización del Nuevo Mundo". Ver Lummis, Charles F., Exploradores españoles del siglo XVI, vindicación de la acción colonizadora española en América (traducción castellana de Arturo Cuyás, Madrid, 2017), pp. 22 ss. 
La iglesia fue una activa colaboradora de la Corona en esta gran tarea. Las órdenes religiosas, como también luego de la secesión, fueron de primera importancia para mantener escuelas y colegios en donde educar a la población. Y las universidades que llegaron a existir en el reino fueron o fundaciones de las órdenes religiosas, como la Universidad conventual de Santo Domingo, la pencopolitana o apoyadas por la Iglesia como la Real Universidad de San Felipe ${ }^{15}$, en la cual la gran mayoría de sus profesores era miembro de alguna de las órdenes religiosas presentes en el país. Especial mención merece la Compañía de Jesús, que al momento de su expulsión regentaba más de 200 colegios y cuyos más destacados miembros figuraban entre los principales académicos de la universidad.

La labor del clero resultó de una importancia capital. Estudios especializados de lengua latina, colegios con rango de universidad pontificia y la academia de filosofía, que dirigía el abogado y conocido cronista, don Manuel Antonio Talavera. Al finalizar la Monarquía Hispánica, solo en Santiago existían "56 escuelas y colegios y 29 establecimientos de estudios superiores"16.

Así, de haber sido efectiva la supuesta política imperial, habría sido absurdo gastar las ingentes sumas que se consumieron en fundar todo este conjunto de establecimientos educativos de primer nivel. Lo que es especialmente valedero para el siglo XVIII, cuando los borbones llevaron adelante sus reformas en el Imperio ${ }^{17}$.

Nos dice Eyzaguirre: "Ha sido aseveración común el que España se esmeró en impedir la difusión del libro en América, con el objeto de mantener a sus habitantes en la ignorancia y más fácil sujeción. Estudios más prolijos de la legislación de Indias y el examen de los documentos que acreditan los embarques realizados para América con permiso de la Casa de Contratación, permiten hoy día llegar a un resultado diverso. Puede ahora afirmarse, sobre buen fundamento, que el libro llegó al Nuevo Mundo con los primeros conquistadores, que su divulgación fue amplia en los siglos siguientes, y que no se circunscribió como se ha afirmado, a las obras de tipo religioso, sino que alcanzó con creces a las de recreación literaria y de formación filosófica y científica. Los inventarios de bienes y difuntos confirman, por otra parte, esta aseveración y revelan a menudo la existencia de bibliotecas de cierta importancia en este extremo del mundo. La prohibición de obras heréticas -equivalente a la que en los países protestantes imperaba para los libros católicos- no fue obstáculo para que se vaciara en América con prodigalidad la rica producción literaria de la edad de oro española y que se consumiera en ella, por ejemplo, gran parte de la primera edición de El Quijote. Con razón ha concluido el profesor de la Universidad de Michigan, Irving Leonard: "Las comparaciones son, a menudo, odiosas; pero la gran cantidad de novelas y lectura amena que en el siglo XVI estuvo a disposición de los lectores en las colonias españolas de América, nos ofrece un contraste con lo que nos ha sido revelado

15 Ver Guarda Gerwitz, Gabriel, El triunfo de la Ilustración, el reino de Chile, 1780-1810, en VV.AA., La América Hispana en los albores de la emancipación, actas del IX Congreso de Academias Iberoamericanas de la Historia (Madrid, 2005), p. 230.

${ }^{16}$ Ibídem, p. 229.

17 Ver Brading, David Anthony, The First America: The Spanish Monarchy, Creole Patriots and the Liberal State 1492-1866 (Cambridge, 1993), pp. 9 ss. 
hasta ahora sobre materia de lecturas disponible en las colonias de Norteamérica de un siglo más tarde" 18 .

Pero si el análisis ha de resultar certero debe partirse por recordar ciertos hechos que por conocidos se suelen olvidar y que los historiadores decimonónicos, buenos conocedores de ellos, convenientemente dejaron en segundo plano, cuando no los silenciaron del todo.

Es el caso de la formación de las grandes bibliotecas. Éstas no fueron un hecho aislado. A las colecciones de las órdenes y conventos, deben sumarse muchas bibliotecas particulares, entre las cuales no son las menores las de juristas chilenos, que contaban en sus catálogos con obras clásicas y modernas de Europa. De hecho, la primera biblioteca pública fue fundada en 1788 por el obispo de Santiago, don Manuel de Alday, con 2058 volúmenes. Abría dos días a la semana y contaba con bibliotecario permanente y medios para los que desearan investigar en sus fondos ${ }^{19}$. Asimismo, hubo muchas bibliotecas privadas. Particularmente notables, por la importancia social y política de sus dueños, son las de don José Antonio de Rojas, don Juan Egaña y don Manuel de Salas, cuya formación examinamos más adelante.

Mientras que para la generalidad del continente americano, la introducción de libros importados desde Europa era cuestión habitual, solo restringida por la distancia y tiempo para recibir las obras importadas, la situación en Chile era muy distinta, pero no por la existencia de una virtual política de censura como los historiadores liberales del siglo XIX supusieron ${ }^{20}$.

Principiemos por reiterar la situación de analfabetismo de la población, cuyas cotas se han situado sobre el $90 \%$. Una cultura cívica en medio de un pueblo sin escritura resulta ciertamente difícil de concebir ${ }^{21}$. Los escasos datos estadísticos sugieren que incluso dicha condición de la población podría haber sido más extendida ${ }^{22}$. Si la inmensa mayoría de la población, incluyendo a las capas superiores

18 Ver Eyzaguirre Gutiérrez., Jaime, Ideario y ruta, cit. (n. 7), p. 71.

19 Ver Guarda Geywitz, Gabriel, cit. (n. 15), p. 233.

${ }^{20}$ Ver Eyzaguirre Gutiérrez, Jaime, Ideario y ruta, cit. (n. 7), pp. 71 ss.

21 “...] nuestra población era campesina y la clase trabajadora yacía en el más completo analfabetismo. Por lo tanto, la vida política será para ellas absolutamente indiferente. No existiendo posibilidad alguna de incorporarlas al juego político, la lucha por la organización del Estado resultó en Chile un movimiento puramente aristocrático. No tuvo, como en los demás países hermanos de la América española, un carácter social, sino de simple predominio político de sectores de la burguesía. En Chile, ni la emancipación, ni la lucha por la organización del Estado comprometieron el vínculo de lealtad y de sumisión absoluta y espontánea del trabajador al patrón, tan característico de la época [...]”. Ver Heise GonZÁlez, Julio, 150 años de evolución institucional (7a ed., Santiago de Chile, 1990), p. 22.

22 Se trata del censo realizado por orden del Presidente Agustín de Jáuregui y Aldecoa entre 1777 y 1779 . Aunque sus resultados solo abarcan al obispado de Santiago y son fragmentarios, puede estimarse que del total de poco más de 800.000 habitantes que en total poblaban el reino (incluyendo españoles, pues los censos no hablan de "criollos" e indígenas), menos del 2\% sabía leer y escribir, o sea, alrededor de 15.000 personas. Ver Censos y empadronamientos, en Memoria Chilena, disponible en http://www.memoriachilena.cl/602/w3-article-95358.html (08-02-2016). Igualmente, pueden consultarse además del censo de Jáuregui, el de Chiloé y el del Gobernador Ambrosio O’Higgins, todos de la segunda mitad del siglo XVIII, en INSTI- 
de la misma, era analfabeta, la difusión de las ideas de la ilustración solo podría ser de muy reducida extensión y además superficial. Los escasos chilenos alfabetos escribían el español con esfuerzo, mal podría pedírseles que hablasen francés ${ }^{23}$.

Así, los círculos de formación intelectual deben haber sido extremadamente reducidos, mucho más de lo que tradicionalmente se apunta. Unas pocas tertulias en Santiago, no más de una docena, y en Concepción la casa de Juan Martínez de Rozas y la de su suegro José de Urrutia Mendiburu, más su círculo de amistades cercanas. Ese era el carácter po pular del grupo de criollos con inquietudes políticas.

En una notable caracterización de la mentalidad de los españoles de Chile nos dice don Fernando Campos: "Hacendados y granjeros, descendientes de conquistadores, conservaban como un legado precioso de sus padres la tradición de lealtad al Rey [...] El entusiasmo patriota de Santiago y Concepción, los centros más poblados, trasmitido en las tertulias patricias [...] era desconocido por estos caballeros de rostro avellanado y tostado, que trabajaban poco, pensaban menos y hablaban el castellano viejo de los conquistadores" ${ }^{24}$.

Lo mismo había dicho ya uno de los historiadores clásicos, tal vez el de juicio más independiente y díscolo según los intereses liberales, por lo menos mucho más que Barros Arana y los hermanos Amunátegui, don Benjamín Vicuña Mackenna. "Con escepción de unas pocas familias pudientes i comprometidas de la capital, el país, campos i ciudades, pueblo y magnates, indios i españoles eran todos realistas hasta la médula de los huesos, i tanto que el verdadero sentimiento democrático, base de las repúblicas, aun no se hace mediano camino ni después de cien victorias, ni después de ochenta años de ensayos, de pruebas i de éxitos" 25 .

Por otro lado, la posibilidad de importar obras literarias directamente desde Europa no era, en teoría, nada de difícil. Es cierto que una cantidad de las obras más representativas del pensamiento ilustrado tenía restricciones de venta e importación por haber sido condenadas por el Santo Oficio de la Inquisición o directamente por la Corona, pero los permisos o licencias que permitían su importación y tenencia resultaban muy usuales y estaban disponibles para cualquier interesado.

tuto Nacional de Estadísticas, Retratos de nuestra identidad: los Censos de Población en Chile y su evolución histórica hacia el Bicentenario (Santiago de Chile, 2009), pp. 50 ss. Consúltese también Duchens, Myriam, Población y Sociedad, en Fermandois Huerta, Joaquín (dir.); Couyoumdjian Bergamali, Ricardo (coord.), Chile, Crisis imperial e independencia, 1808-1830 (Lima, 2010), I, pp. 174 ss.

${ }^{23}$ Sin perjuicio de constar que unos pocos de los más destacados vecinos de Santiago dominaban lenguas extranjeras, como era el caso de José Miguel Infante, don Manuel de Salas, don Juan Egaña y su hijo Mariano y un par más (en el caso de los Egaña su conocimiento alcanzaba a las lenguas clásicas, latín y griego). Pero este hecho más que constituir un desmentido, por su escaso número, no hace más que confirmar la regla general de ignorancia en la población toda.

${ }^{24}$ Ver Campos Harriet, Fernando, Los defensores del rey (Santiago de Chile, 1958), p. 42.

25 Don Benjamín escribía esto en 1884. Ver VicuÑa MaCKenNa, Benjamín, El coronel don Tomás de Figueroa, estudio crítico según documentos inéditos sobre la vida de este jefe y el primer motín militar que acaudilló en la plaza de Santiago el $1^{\circ}$ de abril de 1811, i su proceso (Santiago de Chile, 1884), pp. 140 ss. 
El problema era que su monto resultaba prohibitivo para la inmensa mayoría de la población que podría haber tenido interés de acceder a ellas ${ }^{26}$.

Desde las primeras bibliotecas conventuales del rudo siglo XVI, pasamos a la formación de las primeras colecciones privadas a mediados del barroco siglo $\mathrm{XVII}^{27}$. Hacia 1660 ya existían chilenos que poseían varios cientos de libros ${ }^{28}$. Y el fenómeno continuó en expansión durante el siglo XVIII ${ }^{29}$.

Al día de hoy contamos con una información relativamente completa del total de los miembros de la sociedad nacional que tuvieron acceso a obras de filosofía política y de pensamiento ilustrado, científico y artístico de origen europeo. Tanto Eyzaguirre como Amunátegui Solar han estudiado ampliamente el tema.

En un breve balance podemos señalar que las principales figuras de la dirigencia santiaguina habían tenido algún contacto con esta literatura, pero cuán influyente había sido este contacto en modelar su pensamiento político resulta una especulación completamente aventurada.

Tras la expulsión de los jesuitas del reino en 1767, su biblioteca había quedado clausurada y sus libros en depósito en las dependencias de la Real Universidad de San Felipe ${ }^{30}$. Con todo, muchos de los libros que podríamos calificar de i 1 u s t r a d o s eran escasamente consultados por sus estudiantes, debido a que las cátedras universitarias no los contemplaban como material de estudios. Por ejemplo, la obra del padre Juan de Mariana estaba presente más en la tradición oral y en el recuerdo histórico de las viejas familias chilenas que en su estudio universitario, el que fue desechado al decretarse la extinción de las cátedras destinadas al análisis de su pensamiento. Todo lo que se vinculaba con lo jesuítico era tenido por sospechoso, pero no solo por las autoridades sino por los propios estudiantes de la casa de estudios.

En relación a las bibliotecas particulares, las más características y conocidas de inicios del siglo XIX, fueron las de don José Antonio de Rojas, don Manuel de Salas y don Juan Egaña.

${ }^{26}$ Años más tarde, cuando se fundó el periódico La Aurora de Chile, se produjo un problema similar, pues los ejemplares del medio impreso fueron puestos a la venta a un precio que resultaba excesivo para los potenciales compradores y por ello su circulación fue reducidísima. La razón era la misma, la procedencia del papel, de buena calidad, era francesa o inglesa, y tremendamente cara. De hecho, en tiempos de la consolidación de la República, los gobiernos nacionales tuvieron que subsidiar a los medios de prensa para que pudieran subsistir en una sociedad que continuaba siendo universalmente analfabeta.

27 Ver Villalobos Rivera, Sergio, Tradición y reforma en 1810 (Santiago de Chile, 1961), pp. 69 ss.

28 Ver Solar Correa, Eduardo, Las tres colonias (2a ed., Buenos Aires, 1970), p. 67.

29 El historiador don Gabriel Guarda Geywitz, Premio Nacional de Historia, nos apunta la existencia de muchas bibliotecas con cientos de volúmenes cada una, pertenecientes a personajes de relevancia social, especialmente de juristas, oidores y profesores de la Universidad. Ver Guarda Gerwitz, Gabriel, cit. (n. 15), pp. 231 ss.

30 Dice al respecto don José Toribio Medina: "Finalmente, poniéndose de acuerdo el Rey y el Consejo de Inquisición, ordenaban poco después de la expulsión de los Regulares de la Compañía de Jesús que el Tribunal no se metiese en los libros y papeles prohibidos que se hallasen en las bibliotecas de aquellos". Ver Medina, José Toribio, Historia del Tribunal del Santo Oficio de la Inquisición (Santiago de Chile, 1952), p. 644. 
Respecto del primero, nos consta que tras su estancia en España ingresó al país numerosas obras ilustradas ${ }^{31}$, incluyendo algunas p r o h i b i d as, pero las adquirió con expresa licencia, que compró siguiendo la reglamentación vigente. No se ha estudiado a fondo la utilización personal que hizo de las obras que poseía. Pensamos que facilitó algunos de estos textos a sus allegados ${ }^{32}$, entre los que puede haberse encontrado su gran amigo Juan Martínez de Rozas, pero poco más sabemos al respecto ${ }^{33}$. La personalidad de Rojas resulta igualmente compleja de apreciar a la distancia. Ilustrado sí, pero partidario del rey, al menos en tiempos de la revolución en Francia, y luego juntista, se le ha calificado de medroso y volteriano ${ }^{34}$.

En el caso de don Manuel de Salas, de la misma forma que Rojas, había adquirido una gran cantidad de literatura científica, histórica e ilustrada en España. Pidió y obtuvo licencia para importarlos, pero, a diferencia de Rojas, no fue riguroso en certificar las autorizaciones que había recabado. Contó con la colaboración de la autoridad inquisitorial de Madrid, con cuyos representantes había trabado amistad, por lo que el examen practicado no fue suficientemente exhaustivo. Cuando el envío llegó a las aduanas de Cádiz, la Inquisición andaluza, más estricta que su homóloga de Madrid, retuvo los libros que no contaban con autorización expresa ${ }^{35}$ e inició un proceso en contra de Salas. Este largo pleito, en donde el joven intelectual hubo de deponer en repetidas oportunidades y tuvo

31 Ver Villalobos Rivera, Sergio, cit. (n. 27), pp. 116 ss.

32 “[...] se sabe que Rojas facilitó, entre los años 1808 y 1809, la Enciclopedia y las obras de Bayle, Holbach y Montesquieu, a don Juan Egaña, fray José Javier de Guzmán, don Juan Antonio Ovalle y don José Miguel Infante”. Ver Eyzaguirre Gutiérrez, Jaime, Ideario y ruta, cit. (n. 7), p. 73. Hay que aclarar, eso sí, que muy probablemente los ejemplares de la enciclopedia en poder de Rojas, no correspondían a la colección original completa en francés, sino solo a un par de tomos destinados a la gramática y a la literatura editados en español.

33 Aunque Eyzaguirre afirma que Martínez de Rozas se podría haber contado entre los lectores de la biblioteca de Rojas, no es tan sencillo suponerlo, dado que ambos vivían en las dos ciudades principales del reino muy distantes entre sí. Nosotros pensamos que, si Martínez tuvo acceso a la biblioteca de Rojas, fue mucho antes, en el tiempo en que Rojas visitó Mendoza camino a Chile y trabó amistad con el joven universitario don Juan Martínez. Ver Eyzaguirre GutiérREZ, Jaime, Ideario y ruta, cit. (n. 7), p. 73. Por su parte, don Domingo Amunátegui Solar añade a la biblioteca ilustrada de Rojas, obras de Helvecio, que circulaban por toda América sin grandes restricciones, y la obra del abate Raynal "Historia de los establecimientos europeos en las dos Indias”. Erróneamente sostiene que Rojas habría entrado las obras citadas en forma clandestina, cuando lo correcto es que pagó las licencias debidas por todas ellas. Asimismo, incluye un listado de tres cartas de agradecimiento, en donde sus corresponsales le agradecen por los préstamos: se trata de don José Miguel Infante, los dos Egaña, padre e hijo, don Juan Antonio Ovalle y fray Javier de Guzmán. Ver Amunátegui Solar, Domingo, Génesis de la Independencia de Chile, en Anales de la Universidad de Chile, 118 (Santiago de Chile, 1960), p. 149.

${ }^{34}$ Ver Infante Martin, Javier Francisco, Autonomía, independencia y república en Chile, 1810-1828 (Santiago de Chile, 2014), pp. 47 ss.

35 Entre ellos parecen haberse encontrado los tres tomos de la enciclopedia que Salas había comprado, editados en español y la "Introducción a la historia general y política del universo", de Samuel Puffendorf. Ver Eyzaguirre Gutiérrez, Jaime, Ideario y ruta, cit. (n. 7), p. 72. Un completísimo examen del proceso judicial que debió enfrentar Salas en España puede revisarse en la obra miscelánea del mismo profesor Eyzaguirre, dedicada a la Logia Lautarina, ver EYZAGUIRRE Gutiérrez, Jaime, Don Manuel de Salas, procesado por la Inquisición, ahora, en ÉL MISMO, La logia Lautarina (Buenos Aires, 1973), pp. 83-101. 
que enfrentar un constante examen de su pensamiento, provocó un claro trauma en la personalidad de Salas, que en todo el resto de su vida manifestó un talante timorato y medroso, que lo colocó en el bando de una fidelidad, si no activa, al menos sí duradera, del rey ${ }^{36}$. Asimismo, Salas abandonó cualquier cercanía con las tesis agnósticas ilustradas. Su lectura de Olavide influyó decisivamente en él y le volvió un católico fiel a la doctrina ortodoxa ${ }^{37}$.

En cuanto a la biblioteca de don Juan Egaña, que pasaría a su hijo Mariano, fue obra del notable interés y talento literario de don Juan, abogado, limeño de nacimiento, aunque de orígenes familiares chilenos. Ya hemos visto que ambos se beneficiaron de los préstamos que les hizo don José Antonio de Rojas, quien compartía los libros de su biblioteca generosamente. En poder de Egaña se encontraban obras clásicas latinas y griegas, curiosidad extremadamente sofisticada en el árido panorama intelectual nacional.

Interesante, también, es seguir el caso de don José Miguel Infante, cuya actuación en el Cabildo Abierto de 1810 sería tan significativa, pues tuvo acceso a numerosas obras ilustradas, sea porque las compró o se las facilitaron para su lectura sus propietarios, especialmente su tío materno, José Antonio de Rojas, como ya sabemos por las cartas de agradecimiento enviadas. Su participación política como procurador del Cabildo de Santiago lo distingue como el principal orador en la reunión del 18 de septiembre, en donde sostuvo la legitimidad de conformar una Junta de Gobierno que dirigiese al país mientras continuara el cautiverio del rey don Fernando VII ${ }^{38}$.

En fin, sabemos que compraron licencias don Miguel de Eyzaguirre, luego fiscal de la Audiencia limeña y hermano del alcalde de Santiago, don Agustín, el oidor de la Audiencia don Francisco Tadeo Diez de Medina y don Fernando Márquez de la Plata, quien adquirió la obra de Puffendorf ${ }^{39}$.

36 Ver Villalobos Rivera, Sergio, Tradición y reforma, cit. (n. 27), p. 115.

37 “[...] la publicación en 1798 de El Evangelio en triunfo o Historia de un filósofo convertido, en que el peruano don Pablo de Olavide procesado años antes por la Inquisición por sus doctrinas sospechosas, se retractó del filosofismo cuyos efectos sufrió en los días del Terror en Francia, produjo una honda impresión en Salas, que leyó la obra en Chile y la comentó con elogio". Ver Eyzaguirre Gutiérrez, Jaime, Don Manuel de Salas, cit. (n. 35), pp. 100 ss.

${ }_{38}$ Años más tarde, entrevistado por Gay para la redacción de su Historia de Chile, Infante, que había derivado de posturas políticas liberales a un singular federalismo (que mantendría en solitario y hasta su muerte) afirmó ante el sabio francés, que toda su intervención en los primeros pasos de la secesión había sido una cuidadosa puesta en escena para fingir una lealtad al rey que en verdad no sentía. Es lo que los historiadores rioplatenses y novohispanos han llamado "la máscara de Fernando VII". No podemos estar seguros de la veracidad de estas afirmaciones, que suenan más bien a una tardía justificación de su conducta fidelista que a un auténtico prurito independentista. Ver GaY, Claudio, Historia de Chile, cit. (n. 11), V, p 96. Sobre el interesante y controvertido tema de la máscara de Fernando VII, ver LandaVazo Arias, Marco Antonio, La máscara de Fernando VII: discurso e imaginario monárquicos en una época de crisis, Nueva España, 1808-1822, (México, 2001), 362 pp.

39 Teniendo presente los sentimientos fidelistas de Márquez de la Plata, podemos especular que bien podría haber sido él quien facilitó el ejemplar de esta obra al gobernador García Carrasco, quien debió enfrentar una investigación por libros sin licencia. Ver MedinA, José Toribio, Historia del Tribunal, cit. (n. 30), p. 648. 
No es necesario recordar que la totalidad de los personajes que hemos reseñado brevemente, eran parte de lo que ellos mismos denominaban el p a t r i a r c a d o capitalino, el pequeño sector del pueblo que verdaderamente tenía el poder e influencia social como para conformar una opinión política de alguna relevancia. $\mathrm{Su}$ muy reducido número y alta endogamia deja en evidencia su escasa representación social. La inmensa mayoría de la población española (americana y peninsular) de la ciudad no participaba en lo más mínimo de las inquietudes que movían al grupo reseñado.

Ahora bien, si reducidos eran los cenáculos santiaguinos, más diminutos eran todavía los de la castrense sociedad penquista en Concepción, la barroca ciudad asiento del ejército del Sur ${ }^{40}$.

Mientras que en Santiago de Chile el neoclásico se imponía de la mano de Toesca y Goycolea, en Concepción reinaba aún el barroco indiano, "el estilo preferido por el pueblo" ${ }^{1}$. Y la mentalidad de sus habitantes era igualmente barroca, sinuosa y compleja.

Podemos citar como centro de las discusiones de los que más tarde serían secesionistas, los salones de la familia Urrutia Mendiburu, unida por matrimonio al prócer don Juan Martínez de Rozas ${ }^{42}$, en donde su mujer, doña Nieves Urrutia, brillaba como anfitriona de los pocos amigos de confianza de su marido. Depositaria de los secretos más íntimos de don Juan, doña Nieves guardaría celosamente los testimonios de la acción política de su marido, tal vez demasiado celosamente $^{43}$. En la órbita de los Martínez y Urrutia se movían las familias Prieto, Vásquez de Novoa, De la Cruz, más vínculos familiares con los Zañartu, Trujillo,

40 Según las estimaciones del precenso de 1813, Concepción ciudad tenía en la época alrededor de 10.500 habitantes. Del barroco penquista no queda nada, los terremotos que periódicamente han golpeado a la ciudad se encargaron de destruir ese rico legado hispánico. Ver Guarda GeYwitz, Gabriel, cit. (n. 15), p. 226.

${ }^{41}$ Ver Guarda Gerwitz, Gabriel, cit. (n. 15), p. 247.

42 Martínez de Rozas había enlazado a su familia con la destacada y extendida familia Larraín, la famosa "Casa Otomana” u "ochocientos", como se llamó a los descendientes de don Martín de Larraín y Vicuña, sobrino del Marqués de Larraín. Dos hermanos de Martínez contrajeron matrimonio con hijas de la familia Larraín. Ver CARTEs MONTORY, Armando, Concepción contra "Chile", Consensos y tensiones regionales en la Patria Vieja (1808-1811) (Santiago de Chile, 2010), p. 84.

${ }^{43}$ Una de las más grandes pérdidas documentales para conocer el pensamiento íntimo de Martínez de Rozas, fue la quema completa de su archivo personal que en 1815 llevó a cabo doña Nieves para evitar que del examen de dichos papeles pudiesen encontrarse pruebas que incriminaran a su marido en actividades contrarias al orden legal. Ello era debido a la persecución de los patriotas y sus familias en tiempos de la restauración del orden indiano, época llamada "reconquista" por los historiadores clásicos. El nuevo gobernador, don Mariano de Ossorio, había creado los tribunales de justificación y vindicación que examinaban la actuación de los líderes patriotas y sus papeles privados. Fue lo que motivó a la destrucción del archivo por parte de la viuda de Martínez de Rozas, no obstante que éste había ya fallecido en su exilio de Mendoza. Ver Encina Armanet, Francisco Antonio, Historia de Chile, desde la prehistoria hasta 1891 (2a ed., Santiago de Chile, 1952), VI p. 82. Nuestras estimaciones sobre las fuentes literarias del pensamiento de don Juan Martínez son sólo eso, especulaciones. Basándose en el discurso de inauguración del primer Congreso Nacional que pronunció don Juan en 1811, Eyzaguirre afirma que admiraba a Hobbes, Maquiavelo, Bacon, Grocio, Puffendorf, Locke, 
Benavente, Manzano, Fernández Manzano, Serrano Alfaro y otras. Las amistades más cercanas del abogado Mendocino eran sus cuñados Urrutia, don Fernando de Urizar, don Rafael de la Sotta, don Pedro Ramón Arriagada y el religioso fray Rosauro Acuña de Chillán ${ }^{44}$.

Del resto del país es poco lo que puede decirse, más que señalar que desde el norte en Coquimbo y la Serena ${ }^{45}$, y hasta el extremo sur, con el Archipiélago de

Bodin, Hume, Montesquieu, Rousseau y Mably, pero no tenemos constancia alguna de que haya siquiera leído a estos autores.

${ }^{44}$ Ver Cartes Montory, Armando, cit. (n. 42), p. 35. Sobre todos los nombrados ejercía Martínez de Rozas un poderoso ascendiente. Tal es así que, a poco de asumir el obispado de Concepción, en abril de 1810, monseñor don Diego Antonio Navarro Martín de Villodres, realista sincero y entusiasta, pudo percibir la innegable influencia del mendocino sobre la juventud de la ciudad. Aunque, en razón de lo que hemos dicho antes, pudiéremos estimar exagerada la extensión que le da a las influencias de Martínez, no puede negarse que acertó con precisión al describir los propósitos del mismo. Nos dice en su famosa pastoral de 1814: "Apenas tomamos posesión de esa iglesia, cuando percibimos el germen de la revolución. Los indecentes sarcasmos de Voltaire y las inconsecuentes paradojas de Rousseau habían penetrado hasta el último rincón del mundo; y aunque manejadas con mucha reserva por quien procuraba sondar nuestros pobres conocimientos, no pudieron escapar a la experiencia de veinte años, en que desde el retiro de nuestro estudio habíamos seguido paso a paso, ya por curiosidad, ya por instrucción, los principios, progresos y fines de la revolución de Francia. Alguna que otra vez se nos quisieron indicar al descubierto, aparentando confianza é ingenuidad, como pasatiempo de literatura, pero; una respuesta pronta, vigorosa y llena de indignación, hizo recoger velas al imprudente y atrevido discurso, y volverse a encastillar en su dolosa reserva.

Sin embargo, no dexaban de esparcirse sordamente las perversas máximas, y á cada paso llegaban á nuestros oídos los discursos insensatos de varios jóvenes, que llenos de ignorancia, hablaban de materias de Estado sin entenderlas, se prometían felicidades que soñaban; y lo peor de todo, trataban de lo mas sagrado de nuestra religion con burlas indecentes. Bien veíamos que todos estos rayos partían de un solo foco, en que por desgracia os habían hecho creer residía una consumada sabiduría: error que os ha causado infinitos males, y de que no era fácil sacaros, á causa de las profundas raíces que tenia echadas en vuestros inocentes corazones. Magíster dixit, decían los discípulos de cierto filósofo [Nota del autor: el obispo se refiere aquí sin nombrarlo, a Martínez de Rozas]: y lo mismo decíais vosotros para prueba de los mayores delirios: delirios que ha calificado de tales la experiencia, y de cuyos autores podemos sentar con San Pablo: dicentes se esse sapientes, stulti facti sunt". Ver Navarro Martín de Villodres, Diego Antonio obispo de la Concepción de Chile, Carta pastoral, a todos los fieles, asi eclesiásticos como seculares de su diócesis (Lima, 1814), pp. 4-6. Sobre el particular, ver PACHECO SiLVA, Arnoldo, El aporte de la élite intelectual al proceso de 1810: La figura de Juan Martínez de Rozas, en Revista de Historia, 8/8 (Concepción, 1998) p. 48.

${ }^{45}$ Hasta don Claudio Gay, sin duda con un cierto escándalo para su mentalidad republicana liberal, reconoce el acendrado fidelismo de las ciudades y gentes del norte chileno: "Al norte de Chile, las ideas de libertad y reforma eran totalmente nulas [...] aún tenaces [...] los habitantes de Coquimbo [...] tenían un apego sincero a la monarquía. Este apego, en algunas circunstancias, lo llevaron algunos funcionarios a extremos frenéticos; así es que al advenimiento de Fernando VII a la corona de España, Coquimbo recibió su retrato con una pompa que casi degeneró en culto. Construyeron un carro triunfal para ir a buscarlo al puerto, y, después de haberlo desembarcado con salvas de artillería, lo colocaron en una especie de anfiteatro para llevarlo en triunfo a la ciudad, tirado por catorce soldados, y acompañado de los habitantes de distinción con tambores y música y a la cabeza. Tras de los habitantes, iban dos hileras de doncellitas cantando himnos a aquel nuevo dios, al que otras mujeres, que le rodeaban, incensaban con el incienso de la iglesia. Las autoridades cerraban la marcha, presididas por el sargento mayor D.M. Uriondo, 
Chiloé y Valdivia, la única idea política presente en las mentes de los españoles de Chile, era la de la fidelidad al rey, el temor a los enemigos seculares de la monarquía, los ingleses y luego los franceses, y el deseo de lograr el desarrollo de un reino en donde todo estaba por hacerse. Pues lo que hay que reconocer es que, en los españoles de Chile, se había formado una muy sólida conciencia de su amor y vínculo con el terruño, su identificación con su patria natal, el reino de Chile, la tierra fría y umbrosa aislada del resto del continente por desierto, mares y cordilleras formidables.

Gay reconoce este hecho a regañadientes: “[...] la mayor parte de los chilenos que ocupaban altos puestos eran contrarios a todo espíritu de reforma, como también lo era la clase mediana, sometida enteramente al clero, y generalmente afecta a la Monarquía. Además, las nuevas ideas que empezaban a propagarse eran diversas en su espíritu, y no podían influir de un modo uniforme en los ánimos que las adoptaban" 46 .

La cultura universitaria es otro elemento a considerar para tener claridad sobre la mentalidad de la sociedad chilena en los inicios del siglo XVIII tras las reformas impulsadas por la Casa de Borbón ${ }^{47}$.

autor y maestro de ceremonias de aquella notable ovación. En La Serena, la procesión entró por medio de un gentío a cuyo júbilo se mezclaba con cierto recogimiento religioso que recordaba los tiempos antiguos de idolatría, pues en algunas calles se vieron individuos tan doblegados a la servidumbre que se arrodillaban, y sin duda alguna adoraban el retrato. A su tiempo veremos cómo la primera junta se vio en la necesidad de emplear fuerza y autoridad para darse a reconocer, por donde se ve cuán poco dispuestos estaban a admitir un cambio de gobierno [...]”. Ver GAY, Claudio, Historia, cit. (n. 11), V, p. 36. Más allá del escándalo que suscita en Gay la devoción de los chilenos del norte por el rey, es conveniente recordar que similares ceremonias y entusiasmo se observaban en todo el resto de las monarquías absolutas europeas, partiendo por Francia, en donde el culto a la majestad real alcanzó cotas de insospechado refinamiento. Claro, Gay era un liberal que quería olvidar todas las antiguas costumbres que habían regido a sus propios antepasados. Por su parte Amunátegui nos recuerda los detalles del discurso de Joaquín Pérez de Uriondo: "Nobles i leales coquimbanos: "Ya tenéis en el puerto el retrato de nuestro adorado soberano el señor don Fernando VII, que lo ha conducido de Lima la corbeta nacional la Bretaña, el mismo que tendréis la ocasión; de ver el jueves 13 del presente, en que hará su entrada pública en esta noble ciudad. Recibidle como si fuera el precioso orijinal. Ofrecedle de nuevo vuestros votos i fiel vasallaje. Corred a postraros a sus reales piés, llenos del más profundo respeto, de modo que se conozca en vosotros el amor que justamente le profesáis; i que tenéis el alto honor de ser vasallos del mejor, más grande i mas amado, de los monarcas, el incomparable Fernando VII.: Cubrid vuestras paredes de tapices, i el suelo de flores, para que pase tan augusta persona, ídolo de nuestros corazones; e implorad al Dios de los ejércitos lo restituya cuánto ántes a su, real trono, i confunda al perverso, pérfido e inicuo emperador" de los franceses i sus secuaces.- Coquimbo 11 de julio de 1809.- Joaquin Pérez de Uriondo". Ver Amunátegui, Miguel Luis, Los precursores de la Independencia de Chile (Santiago de Chile, 1870), pp. 113 ss. En el mismo sentido, ver Infante MarTín, Javier Francisco, Autonomía, cit. (n. 34), p. 46.

${ }^{46}$ Ver GaY, Claudio, Historia, cit. (n. 11), V, p. 38. En el mismo sentido se pronuncia Malamud, "Por último, el conservadurismo de las zonas rurales les hizo apoyar con escasas excepciones el bando realista". Ver Malamud Rikies, Carlos et al., Historia de América (temas didácticos) (Madrid, 2004), p. 271.

${ }^{47}$ Ver Barbier Jacques A., Reform and Politics in Bourbon Chile, 1755-1796 (Ottawa, 1980), 218 pp. 
En un país de precaria intelectualidad podría resultar aparentemente contradictorio hablar de c u l t u r a u n i ve r s i t a r i a, pero la verdad es que ella existía y tenía ya en 1800 una larga tradición. Por cierto, la razón de la dicotomía apuntada es fácil de explicar, pues los claustros universitarios recibían a una minúscula parte de la sociedad y los graduados de los mismos no solo desarrollaban su labor en la sociedad civil y dentro del reino, sino que con frecuencia se recluían en los claustros monacales, que fueron los mismos que generaron las universidades, o emigraban a otras provincias y reinos del imperio.

La creación de la universidad fue, en efecto, una obra de la Iglesia Católica, siguiendo aquella larguísima lista de estudios generales que comenzó en Bolonia a fines del siglo XI.

En el reino de Chile la primera fue la Universidad Conventual de Santo Tomás, o universidad dominica, fundada bajo los auspicios de la orden de los predicadores en 1622, en pleno barroco indiano. Fue universidad conventual y pontificia por expresa bula papal ${ }^{48}$. Su primer rector sería fray Martín de Salvatierra, que encabezó una lista de 33 rectores que encabezaron la Universidad hasta mediados del siglo XVIII. Otorgaba grados en artes o filosofía y teología. A ella concurrían tanto seglares como religiosos y también estudiantes trasandinos de Córdoba, Mendoza y Buenos Aires.

Luego vendría la fundación real de la Universidad de San Felipe, cuya cédula de institución fue dada por don Felipe V, en 1738 y que expresaría las inquietudes educativas de la reducida élite social chilena desde el inicio de sus actividades en $1747^{49}$ hasta la primera mitad del siglo XIX. La universidad, cuyo primer rector fue don Tomás de Azúa e Iturgoyen, confería grados de bachiller, licenciado y doctor en teología, filosofía, derecho, más tarde medicina y, por último, matemáticas. Al igual que la precedente, recibía alumnos procedentes de Buenos Aires, Paraguay, $\mathrm{Cuyo}^{50}$ y Tucumán, que por la distancia preferían Santiago de Chile a Lima, pero éstos, una vez graduados, retornaban a sus lugares de origen, sin que pudieran aportar a la cultura en el reino.

\section{La Monarquía HisPÁNiCA y LAS SUPUESTAS COlONIAS}

Veamos ahora el segundo elemento de la interpretación ideológica, el de la naturaleza político-jurídica de Chile, creado, como el resto de los reinos de América, como una simple c o l o n i a . La argumentación sostiene que la Monarquía

48 "Las Universidades Pontificias, a cuya labor educativa coadyuvan los Seminarios Conciliares erigidos en el siglo precedente (XVI) y varios otros institutos de semejante índole, representan el mayor esfuerzo cultural de la época. Ordinariamente se las conoce por el nombre de sus patronos: Santo Tomás, bajo cuya advocación de encontraba la Universidad Dominicana, y San Francisco Javier, protector de la Universidad Jesuita”. Ambas instituciones conferían los grados de bachiller, licenciado y doctor en teología y cánones. Ver Solar Correa, Eduardo, cit. (n. 28), pp. 63 ss.

49 Aunque las aulas solo empezaron a recibir estudiantes a partir de 1758. Ver Bravo LiRA, Bernardino, La Universidad en la Historia de Chile, 1622-1992 (Santiago de Chile, 1992), p. 69.

${ }^{50}$ Fue el caso del prócer don Juan Martínez de Rozas, que obtuvo su doctorado en derecho en Chile. 
Hispánica habría sido de la misma naturaleza que la inglesa, portuguesa o francesa. Una metrópoli que gobierna una serie de factorías o establecimientos de carácter comercial, destinados a la explotación de sus riquezas naturales y en donde los colonos permanecen aislados de la población nativa a la que usualmente esclavizan. La colonia no tenía personalidad jurídica propia ni menos un sistema jurídico particular, pues las leyes aplicables a su población eran las de la potencia colonial. La población de las colonias era considerada de segunda frente a la de los nacidos en la metrópoli, y el matrimonio entre colonizadores y nativas, completamente prohibido. La imagen de las excolonias de Inglaterra en el norte de América, la India o los establecimientos coloniales franceses en África u Oriente se habría aplicado también al Imperio Hispánico.

De allí que los historiadores clásicos hablarían uniformemente de 1 a colo n i a, o los ti e m pos coloniales, para referirse a la historia de cuatro siglos de Monarquía Hispánica.

Nuevamente, es muy interesante contrastar el mito con la realidad. Principiemos por indicar que, en el estado actual de nuestro conocimiento histórico, que es extenso y profundo, nadie empleó nunca el término indicado para referirse a los reinos, provincias o virreinatos americanos durante los siglos XV a XVII. Nunca se usó de la expresión colo n i a ni en su sentido jurídico ni menos político. Solo a fines del siglo XVIII, y en un ámbito muy preciso, el de la producción de manufacturas en América, algunos ministros de la monarquía emplearon el término para simbolizar la importancia de mantener a los reinos de América como economías complementarias y dependientes de la peninsular ${ }^{51}$. Jamás se usó la expresión c ol o n o para referirse a los españoles americanos, que es como se llamaban a sí mismos los naturales del Nuevo Mundo ${ }^{52}$.

Es lo que en su momento destacaba el prócer argentino, don Mariano Moreno, al destacar la proclama del Consejo de Regencia de febrero de 1810: "Uno de los rasgos más justos, más magnánimos, más políticos, fue la declaración de que las Provincias no eran una Colonia o Factoría como las de otras Naciones; que ellas formaban parte esencial e integrante de la Monarquía española; y en consecuencia de este nuevo ser, como también en justa correspondencia de la heroica lealtad y patriotismo que había acreditado a la España en los críticos apuros que la rodea-

51 En tal sentido lo usa el escribano de Quito, avecindado en Chile, don Ignacio de Torres, en su informe a la Junta de Aranjuez de 1809. Ver DE TORRES, Ignacio, Informe de don Ignacio de Torres a la Junta Central de Aranjuez sobre varios sucesos ocurridos en Santiago de Chile en los años de 1808-1809, en Colección de historiadores $i$ de documentos relativos a la independencia de Chile (Santiago de Chile, 1902) VIII, pp. 17, 18 y 31.

${ }^{52}$ El propio Bernardo O'Higgins lo reconoce en su famoso decreto de 3 de junio de 1818, sobre el empleo del nombre Chile y “chilenos" tras la declaración de secesión o independencia, refiriéndose a la forma tradicional de denominar a los habitantes del país recordaba: "Fulano, español, natural de Penco”. Ver O’Higgins Riquelme, Bernardo, El “decreto” que nos llamó chilenos, en Andrades Rivas, Eduardo, Textos fundamentales para el estudio de la Historia del Derecho, colección de documentos y fuentes primarias para la Historia del Derecho, con comentarios y cuestionarios (Santiago de Chile, 2017), pp. 645-648. 
ban, se llamara a estos Dominios a tener parte en la Representación Nacional, dándoseles voz y voto en el Gobierno del Reyno" 53 .

¿Cómo se produjo entonces la adopción del término colo n i a para denominar a la etapa histórica de la Monarquía Hispánica? La respuesta hay que buscarla en la decisión política de los líderes de la secesión, que buscaban asegurar la validez política de su victoria militar. Unas provincias o reinos alzados en contra de su gobernante de iure no podían esgrimir ninguna legitimidad para fundar r e públi c a s. Pero unas c ol o n i a s, alzadas en contra de un tirano, tenían evidentemente la legitimidad fundada en la libertad natural de los hombres que luchaban por reivindicar este derecho esencial que les había sido arbitrariamente negado ${ }^{54}$. Es la razón por la que O'Higgins habló de la e s c la v i t u d ${ }^{55}$, metáfora ciertamente exagerada pero ilustrativa de lo que se quería dejar en claro. Y a partir de este momento la fortuna de la voz c o l o n i a iría en alza, al menos en el habla usual de los chilenos cultos, imbuidos del nuevo espíritu republicano ${ }^{56}$.

En el plano de la historia jurídica que analizamos, la expresión c o l o n i a no aparece, por cierto, en la obra del historiador del rey, fray Melchor Martínez, quien nos habla en los términos tradicionales de reino ${ }^{57}$. Ni tampoco en la de fray José Javier de Guzmán, pese a haber sido publicada ya en tiempos de la consolidación de la república ${ }^{58}$.

La responsabilidad de emplear el término en su sentido político reseñado corresponde a don Claudio Gay. Es en el tomo I de la Historia física y política de Chile, redactado por el propio Gay, en donde utiliza por primera vez el vocablo ${ }^{59}$. El libro fue publicado en Francia en 1844 y difundido en Chile a fines del mismo año.

53 Ver Levene, Ricardo, Las indias no eran colonias (Buenos Aires, 1951), p. 128.

${ }^{54}$ Es lo que sostiene el autor bajo pseudónimo del Catecismo Político Christiano de 1810, primer texto que circuló en Chile en donde su hizo mención al término c o 1 o n i a .

55 "Elegid entre ser libres en América, ó esclavos en vuestra patria; entre hacer la guerra como la hacen las naciones cultas, ó como los pueblos bárbaros. Elegid; y no os quejéis de la suerte que debe tocaros por vuestra elección”. Ver O’Higgins Riquelme, Bernardo, Proclama del Excelentísimo Señor Brigadier General don Bernardo O'Higgins, Supremo Director del Estado de Chile, Gefe de la Legión de Mérito, a los Soldados Españoles destinados á la expedición contra Buenos Ayres, en Memoria ChilenA, disponible en http://www.memoriachilena.cl/602/w3article-98631.html (09-09-2016).

56 Así, el 7 de junio del año 1839 encontramos una mención a la c o l o n i a , en las conversaciones que condujeron a la creación de la Sociedad Chilena de Historia y Geografía. En una de las primeras reuniones preparatorias de la tradicional entidad cultural chilena, uno de sus impulsores, don Tomás Zenteno, pronunció un discurso en donde hizo alusión al y u g o c o 1 o n i a 1 . Ver Zenteno, Tomás, Discurso de don Tomás Zenteno, en Revista de Chilena de Historia y Geografía, 67/71 (Santiago de Chile, 1930), pp. 239.

57 Ver MarTínez, fray Melchor, Memoria Histórica sobre la Revolución de Chile Desde el Cautiverio de Fernando VII hasta 1814. Escrita por Orden del Rey por fray Melchor Martínez, en FELIÚ Cruz, Guillermo (ed.) (3a ed., Santiago de Chile, 1964), I y II, pp. 360 y 424, respectivamente.

58 De GuZmán LeCAROs, José Javier, El chileno instruido en la historia topográfica, civil y política de su pais (Santiago de Chile, 2012), 586 pp.

59 En el capítulo XVI al referirse al viaje de Pedro de Valdivia a Perú, que culminaría con la confirmación del conquistador como Gobernador de Chile, Gay sostiene que el viaje tenía por objeto dar auxilio al virrey La Gasca en contra de las rebeliones de los Pizarro. Afirma que don Pedro de Valdivia habría convencido a sus hombres de la necesidad del viaje para defender 
Siguiendo su ejemplo, en diciembre de $1847^{60}$, don José Victorino Lastarria editaba su Bosquejo histórico de la Constitución del Gobierno de Chile, durante el primer periodo de la revolución, desde 1810 a 1814, en donde siguió entusiasta a Gay afirmando la calidad de c o l o n i a respecto del reino de Chile ${ }^{61}$. Todo ello con una fuerte carga crítica negativa en su descripción de la etapa histórica anterior a la secesión.

Y tan solo dos meses después, en enero de 1848, don Manuel Antonio Tocornal y Grez publicaría Memoria sobre el primer gobierno nacional, leida en la sesión pública de la Universidad de Chile el 7 de noviembre de 1847, en la que, igualmente, empleaba la expresión c o 1 o n i a ${ }^{62}$.

Tras Lastarria y Tocornal toda la historiografía clásica del siglo XIX y gran parte del XX ha continuado haciendo uso de una expresión tan vacía de significado histórico y jurídico como ella, pese a las incontables pruebas de su completa falsedad. La explicación, como hemos dicho, hay que buscarla en el plano de la sociología política, antes que en los hechos históricos.

Pero el mito va mucho más allá de una simple palabra. Lo que está en el fondo de la cuestión es desconocer la naturaleza jurídica y política de los reinos de América y la de la misma Monarquía Hispánica. Frente a una supuesta E s paña dominadora de colonias, lo que corresponde es hablar de

los derechos del Emperador, con lo que se evitaría la "llama devoradora que podía cundir hasta los umbrales de la pacífica colonia de Santiago, cuyos intereses reclamaban una esmerada protección" (nota del autor: las espaciadas son nuestras). Ver GAY, Claudio, Historia Física y Politica de Chile, Historia (Santiago de Chile, 2007), I, p. 128.

${ }^{60}$ En rigor, dos meses antes, en octubre de 1847, en un relato personal, un perfil biográfico editado sobre su pariente don José Miguel del Solar, arcediano de la Catedral de Santiago de Chile, la insigne poetisa chilena, doña Mercedes Marín del Solar, al describir el entorno de la vida de su biografiado, se refería a dificultad que hubo en tiempo de la secesión de "uniformar en aquella primera época la opinion a favor de un sistema que trastornaba antiguas instituciones que apoyabam de consuno el interes de muchos, i la ignorancia i preocupaciones de casi todos los que habían vivido bajo el réjimen colon ial" (nota del autor: las espaciadas son nuestras). Ver Amunátegui, Miguel Luis, D. Mercedes Marín del Solar (Santiago de Chile, 1867), p. 52. Sería entonces la segunda persona que en Chile habría usado la expresión colonia, aunque lo hizo en una obra más bien literaria que histórica.

${ }^{61}$ En su caso, en el primer párrafo del capítulo I del libro sobre la constitución del gobierno en 1810 y 1811 nos dice: "El gobierno de Chile durante la dominación española, no es propiamente otra cosa que una administración subalterna, arreglada según el sistema, no siempre fijo, adoptado por la España para el réjimen de sus colonias" (nota del autor: las espaciadas son nuestras). Ver LaSTARRIA, José Victorino, Bosquejo histórico, cit. (n. 1), p.7.

${ }^{62}$ Tocornal critica la conducta moral de los gobernantes hispánicos indicando que: "Encorbados bajo el peso del despotismo peninsular, los vicios i preocupaciones de la metrópoli se reflejaban en sus colonias; en sus colonias decimos, tomando esta palabra en el sentido mas odioso, porque tales eran las secciones de América a los ojos de los déspotas que miraron con criminal desden las joyas mas preciosas de la corona" (nota del autor: las espaciadas son nuestras). Ver Tocornal, Manuel Antonio, Memoria sobre el primer gobierno nacional, leída en la sesión pública de la Universidad de Chile el 7 de noviembre de 1847 (Santiago de Chile, 1848), p. 16. Vicuña Mackenna ha destacado esta memoria como el más importante escrito del autor. Ver Vicuña Mackenna, Benjamín, Don Manuel Antonio Tocornal [reseña biográfica] (Santiago de Chile, 1865), pp. 105-110, en Memoria Chilena, disponible en www.memoriachilena.cl/ archivos2/pdfs/MC0004535.pdf (20-01-2017). 
una monarquía plural, integrada por distintos reinos o provincias dotados de sus propias tradiciones, costumbres, leyes y sistemas políticos, que ni siquiera el absolutismo borbónico había podido barrer del todo. En el caso de América, sus reinos se incorporaron por vía accesoria a la monarquía castellana, y prontamente adquirieron sus particularidades distintivas tanto en lo político como en lo jurídico.

Así, a partir de 1524, no sería un miembro del Consejo de Castilla ${ }^{63}$ sino un consejo diverso y autónomo, creado a imagen del anterior y llamado Real y Supremo Consejo de las Indias el que, colaborando con el rey, dirigiría todos los asuntos relativos al Nuevo Mundo y Filipinas.

Las autoridades de Indias, partiendo por los virreyes, gobernadores y oidores de las audiencias, serían seleccionadas entre los más altos funcionarios de la monarquía y estas funciones no estarían cerradas a naturales de las Indias, como la historia ha demostrado. Eso sí, quienes en principio no podían prestar sus servicios como funcionarios eran los naturales de los otros reinos de la península, estando reservados los cargos a castellanos y americanos. Las excepciones solo vinieron a confirmar la regla.

Las designaciones de americanos en cargos de autoridad fueron, en sus comienzos, más bien escasas, pero ello no se debe a una supuesta discriminación en contra de c o l o n o s, sino simplemente a que la población de españoles americanos era todavía pequeña en los siglos XVII y XVII. En el siglo XVIII en cambio, con el aumento de la población local, se puede apreciar un gran adelanto en la materia. Casi la mitad de los obispos era de origen americano, una cantidad creciente de gobernadores también lo fueron e incluso en el caso de Chile, como en el de otros reinos de Indias, la mayoría de los oidores de la Real Audiencia fueron también naturales del reino ${ }^{64}$.

En el plano jurídico, la extensa y compleja legislación de Indias, aplicable exclusivamente al continente americano y Filipinas, con todas sus normas protectoras de los indígenas, y el establecimiento y regulación de órganos e instituciones particulares de gobierno prueba, sin duda, que no es posible hablar de colonias dependientes de una metrópoli.

No, no existió una España dominadora de colonias, sino la citada monarquía plural, integrada por reinos unidos por la Corona en un pie de igualdad jurídica, fueran de la Península o del Nuevo Mundo.

El profesor Ricardo Levene estudió el tema con detalle y publicó en $1951 \mathrm{su}$ conocida obra Las Indias no eran colonias. La originalidad y fundamento de esta

63 El famoso obispo Rodríguez de Fonseca, nombrado por los Reyes Católicos para preocuparse de los asuntos de Indias.

${ }^{64}$ Hay que destacar que el Real Acuerdo chileno, el más alto tribunal de la Monarquía, que representaba directamente a la persona del Monarca y que defendió con orgullo y dignidad los derechos de la Corona frente a los novadores o juntistas, estaba integrado en 1810 por una mayoría de españoles americanos, provenientes de Buenos Aires y del propio reino o Capitanía General de Chile. La imagen de una Audiencia compuesta por peninsulares fanáticos no es más que otro elemento del mito. 
tesis radica en que logró demostrar, más allá de cualquier polémica, la verdadera naturaleza de los reinos de Indias, cuestión que nadie ha debatido hasta hoy ${ }^{65}$.

El análisis jurídico de Levene es contundente al respecto, y sostiene que las Indias no podrían haber sido colonias debido a que:

i) Fueron incorporadas a la Corona de Castilla por donación papal según la inspiración de los Reyes Católicos y que no podían ser enajenadas;

ii) Los españoles americanos eran iguales en derechos a los españoles europeos, lo que se demuestra por la completa legitimidad de celebrar matrimonios entre ambos grupos, incluyendo a los indígenas. Es en esta posibilidad de b o d a s m e s t i z a s ${ }^{66}$, en que se fundamenta el carácter distintivo del mundo barroco indiano, una sociedad que no es europea, encerrada en sus barrios exclusivos, sino morena, mestiza y heredera de las dos tradiciones, española y americana;

iii) Los descendientes de españoles peninsulares nacidos en América, que fueran beneméritos de Indias, debían ser preferidos en la provisión de los oficios o cargos de autoridad;

iv) El Consejo de Indias tenía la misma jerarquía y poderes que el Consejo de Castilla, compartiendo su condición de altas potestades políticas;

v) Las instituciones regionales como los virreinatos o provinciales, como las gobernaciones, ostentaban en América la plena potestad legislativa ${ }^{67}$;

vi) Tal y como lo ordenó don Felipe II, siendo de una misma Corona los reinos de Castilla y León e Indias, las leyes y órdenes de gobierno de ambos debían asemejarse las unas a las otras;

vii) El derecho indiano se aplicaba con preferencia al castellano en el ámbito americano, y solo en caso de que una situación no hubiese sido especialmente normada para las Indias se aplicaba el derecho de Castilla, según el orden esta-

${ }^{65}$ De muy reciente publicación, contamos con el interesante trabajo del profesor Philippe Castejón, quien formula algunas novedosas observaciones que matizan las apreciaciones clásicas de Levene. Afirma que la palabra c o l o n i a fue ocupada "a partir de 1760, como una herramienta para comprender las reformas económicas”. Ver CASTEJÓN, Philippe, "Colonia” y "Metrópoli", La génesis de unos conceptos históricos fundamentales (1760-1808), en Illes i Imperis, 18 (Barcelona, 2016), p. 164

${ }^{66}$ Los más simbólicos de estos matrimonios fueron los que unieron a las princesas incas con los conquistadores y parientes de Santos. Se les representa en un famoso lienzo del siglo XVII que se conserva en la Iglesia de San Ignacio del Cuzco, en donde aparecen representados los enlaces matrimoniales de doña Beatriz Clara Coya, princesa inca, con don Martín García Oñez de Loyola, sobrino de San Ignacio, y la hija de ambos, doña Ana María Coya de Loyola, marquesa de Santiago de Oropesa, con Juan de Enríquez de Borja y Almansa, nieto de San Francisco de Borja y marqués de Alcañices.

67 “Teóricamente, y en razón del ligamen directo de las Indias con la corona de Castilla, el rey era el único poder legislativo para América. El monarca, en la práctica, asociaba a su función legislativa otros organismos, pero siempre de exclusiva vigencia para las Indias y libres de toda intervención de autoridades propiamente peninsulares [...] la suprema autoridad legisladora con radicación en la metrópoli, era el Consejo de Indias, y las autoridades legisladoras con sede en América eran principalmente los virreyes, gobernadores, audiencias y cabildos, los últimos en representación de la comunidad". Ver Eyzaguirre Gutiérrez, Jaime, Historia del Derecho (15ª ed., Santiago de Chile, 1998), p. 147. 
blecido en el Ordenamiento de Alcalá taurino y reiterado en las recopilaciones de Leyes de Castilla e Indias;

viii) La Corona mandó incluso reemplazar la expresión c o n qu is t a por la de p oblación y pacific a c i ón, para denotar la importancia de la labor civilizadora y fundadora de $\mathrm{r}$ e in os n u e vos que la Monarquía Hispánica llevaba adelante en el Nuevo mundo ${ }^{68}$.

Así, finaliza Levene: "De ahí la conclusión de que España ha formado política y jurídicamente, de estas Provincias, Reinos, Dominios o Repúblicas Indianas -que no eran Colonias o Factorías, según las leyes- nacionalidades independientes y libres" 69 .

Es lo que Konetzke sostiene igualmente ${ }^{70}$. Por su parte Castejón, profundizando en el tema, sostiene que, a fines del siglo XVIII, la expresión c o l o n i a dejó de poseer en un significado meramente migratorio para las autoridades hispánicas, para pasar a tener uno económico. Pero queda a salvo la conclusión leveniana, de que nunca tuvo un significado político ${ }^{71}$. A la misma conclusión llegan los profesores Burkholder y Chandler en su estudio sobre la reorganización imperial en tiempos borbónicos ${ }^{72}$.

\section{Conclusiones}

$1^{\circ}$ La afirmación de haber sido Chile una colonia habitada por gentes mantenidas expresamente en la ignorancia, es una idea sostenida por la historiografía liberal decimonónica, que no se basa en los hechos históricos sino en la concepción ideológica que sirvió de base para la construcción del mito republicano.

$2^{\circ}$ La Monarquía Hispánica no fue una potencia colonial en el sentido de lo que luego serían los imperios francés, holandés o británico, sino una construcción política plural, integrada por distintos reinos situados a ambos lados del océano Atlántico que, dotados de sus propias instituciones y tradiciones jurídicas, se articulaban en torno a la figura del monarca como vértice orientador y rector.

$3^{\circ}$ La política educativa de la Corona resulta indesmentible. Desde los inicios de la población del continente americano y hasta las postrimerías del periodo indiano, la monarquía llevó adelante un vasto y ambicioso plan de enseñanza que partía en la educación primaria de los americanos y los indígenas, seguía con la

${ }^{68}$ Extendiendo el argumento, Castejón acepta que nunca las autoridades usaron del vocablo "colonia" en los documentos oficiales, aunque sí lo usaron en los privados. Ver Castejón, Philippe, cit. (n. 65), p. 172.

69 Ver Levene, Ricardo, Las Indias no eran Colonias, cit. (n. 53), pp. 10 ss.

70 Ver KonetzKe, Richard, La condición legal de los criollos y las causas de la Independencia, en Estudios Americanos, 5/2 (Sevilla, 1950), p. 45.

${ }^{71}$ Castejón cita debidamente el Reglamento y aranceles para el comercio libre de España e Indias de 1778, que sólo usaba del término c o 1 o n i a para referirse a Luisiana, que había sido devuelta a la Monarquía Hispánica en 1763 por los franceses que la habían llamado así bajo su mandato. Sería, entonces, la única excepción motivada por la influencia gala. Ver CASTEJÓN, Philippe, cit. (n. 65), pp. 167, 170.

72 Burkholder, Mark A.; Chandler, Dewit, De la impotencia a la autoridad: la Corona española y las Audiencias en América 1687-1808 (México, 1984), 478 pp. 
educación secundaria, con especial énfasis en las artes y oficios, y culminaba en la fundación de las universidades que entregaban su formación a las élites americanas.

$4^{\circ}$ En Chile esta política se veía limitada por la pobreza general del reino derivada de la circunstancia endémica de la Guerra de Arauco y de la lejanía de los centros más poblados del continente, pero aún aquí se concretaron iniciativas culturales de primer nivel como los colegios de indígenas y los centros universitarios, las universidades pontificias y conventuales y finalmente la Universidad de San Felipe, que coronaron un enorme esfuerzo de la Corona por llevar la cultura a todos los rincones del reino. Los chilenos ilustrados del siglo XVIII fueron el resultado de esta política.

$5^{\circ}$ La sociedad chilena, acostumbrada a la pobreza y limitación de sus medios materiales, vio florecer las bibliotecas privadas y si bien es cierto que la actividad editorial fue escasa, debido a los altos costos de la impresión de libros y a la casi universal condición de analfabetismo derivada de la misma pobreza, no es menos cierto que existió y fue considerable, con lo que el mito de la prohibición de operar imprentas en el reino cae por su propio peso.

$6^{\circ}$ El sistema indiano no contó con c o lo n i as, en el sentido político del término. Los reinos de América y Filipinas, incluido Chile, fueron entidades políticamente similares a los reinos de la Península y su gobierno estaba confiado a autoridades que tenían el mismo nivel jerárquico de las de Europa, partiendo por el Real y Supremo Consejo de las Indias, en todo similar al Consejo de Castilla.

$7^{\circ}$ La mera expresión c o l o n i a nunca fue usada en el sentido que le ha asignado la teoría política contemporánea. De hecho, era desconocida del todo entre los siglos XVI y XVII. Solo en el siglo XVIII algunos ministros de la monarquía la usaron en una mínima cantidad de oportunidades para señalar la necesidad de articular económicamente la producción americana para hacerla complementaria de la peninsular.

$8^{\circ}$ El empleo del vocablo solo se generalizó en Chile a partir de la obra de don Claudio Gay, quien fue el primero en usarla para bautizar al periodo de la Monarquía Hispánica de cuatro siglos. Los sucesivos historiadores nacionales, hasta el mismo siglo XXI y, con ellos, los libros de texto para estudiantes, han seguido usándolo más por inercia inconsciente que por verdadera convicción política. Así, el mito republicano se perpetúa sin que exista interés por ponerle fin.

\section{BiBLIOGRAFÍA}

\section{FUENTES PRIMARIAS}

Henríquez, fray Camilo, Aurora de Chile [prospecto de febrero de 1812], en AuRORA DE CHILE, disponible en: http://www.auroradechile.cl/newtenberg /681/ article-11907.html.

Navarro Martín de Villodres, Diego Antonio, Obispo de la Concepción de Chile, Carta pastoral, a todos los fieles, asi eclesiásticos como seculares de su diócesis (Lima, 1814), pp. 4-6. 
FUENTES BIBLIOGRÁFICAS GENERALES Y MONOGRAFÍAS

Amunátegui, Miguel Luis, D. Mercedes Marín del Solar (Santiago de Chile, 1867), $63 \mathrm{pp}$.

AmunÁtegui, Miguel Luis, Los precursores de la Independencia de Chile (Santiago de Chile, 1870), $364 \mathrm{pp}$.

Barbier, Jacques A., Reform and Politics in Bourbon Chile, 1755-1796 (Ottawa, 1980), 218 pp.

Brading, David Anthony, The First America: The Spanish Monarchy, Creole Patriots and the Liberal State 1492-1866 (Cambridge, 1993), 761 pp.

Bravo Lira, Bernardino, La Universidad en la Historia de Chile, 1622-1992 (Santiago de Chile, 1992), 456 pp.

Burkholder, Mark A.; Chandler, Dewit, De la impotencia a la autoridad: la Corona española y las Audiencias en América 1687-1808 (México, Fondo de Cultura Económica, 1984), 478 pp.

Campos Harriet, Fernando, Los defensores del Rey (Santiago de Chile, 1958), 156 pp.

Cartes Montory, Armando, Concepción contra "Chile", consensos y tensiones regionales en la Patria Vieja (1808-1811) (Santiago de Chile, 2010), 260 pp.

De GuZmán Lecaros, José Javier, El chileno instruido en la historia topográfica, civily politica de su pais (Santiago de Chile, 2012), 586 pp.

De Torres, Ignacio, Informe de don Ignacio de Torres a la Junta Central de Aranjuez sobre varios sucesos ocurridos en Santiago de Chile en los años de 1808-1809, en Colección de Historiadores i de documentos relativos a la Independencia de Chile (Santiago de Chile, 1902), VIII, 373 pp.

Duchens, Myriam, Población y Sociedad, en Fermandois Huerta, Joaquín (dir.); Couyoumdian Bergamali, Ricardo (coord.), Chile, Crisis imperiale independencia, 1808-1830 (Lima, 2010), I, 328 pp.

Encina Armanet, Francisco Antonio, Historia de Chile, desde la prehistoria hasta 1891 (2a ed., Santiago de Chile, 1952), VI, 744 pp.

Eyzaguirre Gutiérrez, Jaime, Historia de las Instituciones políticas y sociales de Chile (8a ed., Santiago de Chile, 1988), 216 pp.

Eyzaguirre Gutiérrez, Jaime, Historia del derecho (15ª ed., Santiago de Chile, 1998), $238 \mathrm{pp}$.

EyZAGUIRRE GutiérREZ, Jaime, Ideario y ruta de la emancipación chilena (Santiago de Chile, 1957), 160 pp.

EyZAguirre Gutiérrez, Jaime, Don Manuel de Salas, procesado por la Inquisición, ahora, en Él Mismo, La logia Lautarina (Buenos Aires, 1973), 236 pp.

Galdames, Luis, Historia de Chile, la evolución constitucional (Santiago de Chile, 1925), I, p. 21.

GaY, Claudio, Historia Física y Política de Chile, Historia (Santiago de Chile, 2007), I, $354 \mathrm{pp}$.

GaY, Claudio, Historia Física y Política de Chile, Historia (Santiago de Chile, 2007), V, 308 pp.

Guarda GEYwitz, Gabriel, El triunfo de la Ilustración, el reino de Chile, 1780-1810, en La América Hispana en los albores de la emancipación, Actas del IX Congreso de Academias Iberoamericanas de la Historia (Madrid, 2005), pp. 225-248.

Heise González, Julio, 150 años de evolución institucional (7a ed., Santiago de Chile, 1990), $158 \mathrm{pp}$. 
Infante Martin, Javier Francisco, Autonomía, Independencia y República en Chile, 1810-1828 (Santiago de Chile, 2014), 312 pp.

KONETZKe, Richard, América Latina, la época colonial (6a ed., traducción castellana de Pedro Scaron, Siglo XXI editores S.A., México, 1977), 402 pp.

LandaVAzo ARIas, Marco Antonio, La máscara de Fernando VII: discurso e imaginario monárquicos en una época de crisis, Nueva España, 1808-1822 (México, 2001), $362 \mathrm{pp}$.

Lastarria, José Victorino, Bosquejo histórico de la Constitución del Gobierno de Chile, durante el primer periodo de la revolución, desde 1810 a 1814 (Santiago de Chile, 1847), $222 \mathrm{pp}$.

Levene, Ricardo, Las Indias no eran Colonias (Buenos Aires, 1951), 176 pp.

Lummis, Charles F., Exploradores españoles del siglo XVI, Vindicación de la acción colonizadora española en América (traducción castellana de Arturo Cuyás, Madrid, 2017), 280 pp.

Malamud Rikles, Carlos et al., Historia de América (temas didácticos) (Madrid, 2004), $525 \mathrm{pp}$.

MarTíneZ, fray Melchor, Memoria Histórica sobre la Revolución de Chile Desde el Cautiverio de Fernando VII Hasta 1814. Escrita por Orden del Rey por Fray Melchor Martínez ( $3^{\text {a }}$ ed., Santiago de Chile, 1964), I y II, pp. 360 y 424 respectivamente.

Martínez Lavín, Manuel, Biografía de Juan Martínez de Rozas (Santiago de Chile, Imprenta Albión, 1894, 150 pp.

Medina, José Toribio, Historia del Tribunal del Santo Oficio de la Inquisición (Santiago de Chile, 1952), 644 pp.

Méndez Montero, Verónica et al., Guía Didáctica para el profesor, incluye texto para el estudiante, Historia, Geografía y Ciencias Sociales, $2^{\circ}$ educación media (Santiago de Chile, 2009), 144 pp.

Mendizábal Cortés, María Antonieta; Riffo Pastrana, Jorge, Texto del estudiante, Historia, Geografia y Ciencias Sociales, $2^{\circ}$ medio (Santiago de Chile, 2013), 352 pp.

O’Higgins Riquelme, Bernardo, El “decreto" que nos llamó chilenos, en ANDRAdEs Rivas, Eduardo, Textos fundamentales para el estudio de la Historia del Derecho, colección de documentos y fuentes primarias para la Historia del Derecho, con comentarios y cuestionarios (Santiago de Chile, 2017), pp. 645-648.

Santibáñez Galleguillos, Lucía; Muñoz Araya, Paola; Riffo Pastrana, Jorge, Guía didáctica del docente, Historia, Geografía y Ciencias Sociales, $2^{\circ}$ medio (Santiago de Chile, 2013), 198 pp.

Solar Correa, Eduardo, Las tres colonias (2a ed., Buenos Aires, 1970), 144 pp.

Tocornal, Manuel Antonio, Memoria sobre el primer gobierno nacional, leida en la sesión pública de la Universidad de Chile el 7 de noviembre de 1847 (Santiago de Chile, 1848), 245 pp.

VARGas Cariola, Juan Eduardo, Las reacciones chilenas ante los sucesos de España, en Silva Vargas, Fernando; Vargas, Juan E. (eds.), 1808 1824, Historia de la república de Chile, el fin de la Monarquía y los orígenes de la república (Santiago de Chile, 2013), pp. 778.

Vicuña Mackenna, Benjamín, El coronel don Tomás de Figueroa, estudio crítico según documentos inéditos sobre la vida de este jefe y el primer motín militar que acaudilló en la plaza de Santiago el $1^{\circ}$ de abril de 1811, i su proceso (Santiago de Chile, 1884), 336 pp. 
Vicuña Mackenna, Benjamín, Historia crítica y social de la ciudad de Santiago, 15411868 ( $2^{a}$ ed., Santiago de Chile, 1926), II, 517 pp.

Villalobos Rivera, Sergio, Tradición y reforma en 1810 (Santiago de Chile, 1961), $248 \mathrm{pp}$.

\section{Artículos de Revistas}

Amunátegui Solar, Domingo, Génesis de la Independencia de Chile, en Anales de la Universidad de Chile, 118 (Santiago de Chile, 1960), pp. 146-164.

Castejón, Philippe, "Colonia" y "Metrópoli", La génesis de unos conceptos históricos fundamentales (1760-1808), en Illes i Imperis, 18 (Barcelona, 2016), pp. 163-179.

InFANTE MarTin, Javier Francisco Jesús, La historiografía constitucional en la formación nacional de Chile: 1810-1833, enfoques y discusiones, en Revista de Chilena de Derecho, 41/2 (Santiago de Chile, 2014), pp. 747-764.

KONETZKe, Richard, La condición legal de los criollos y las causas de la Independencia, en Estudios Americanos, 2/5 (Sevilla, 1950), pp. 31-54.

Pacheco Silva, Arnoldo, El aporte de la élite intelectual al proceso de 1810: La figura de Juan Martínez de Rozas, en Revista de Historia, 8/8 (Concepción, 1998) pp. 43-63.

Suárez Verdeguer, Federico, El problema de la independencia de América, en Anales de la Fundación Francisco Elías de Tejada, 12 (Madrid, 2006), pp. 47-57.

Zenteno, Tomás, Discurso de don Tomás Zenteno, en Revista de Chilena de Historia y Geografia, 67/71 (Santiago de Chile, 1930), pp. 238-241.

\section{FuENTES ELECTRÓNICAS}

Censos y empadronamientos, en Memoria Chilena, disponible en http://www. memoriachilena.cl/602/w3-article-95358.html (08-02-2016).

Instituto Nacional De Estadísticas, Retratos de nuestra identidad: los Censos de Población en Chile y su evolución histórica hacia el Bicentenario, Feyser Ltda., Santiago de Chile, 2009, pp. 50 ss.

O’Higgins Riquelme, Bernardo, Proclama del Excelentísimo Señor Brigadier General don Bernardo O'Higgins, Supremo Director del Estado de Chile, Gefe de la Legión de Mérito, a los Soldados Españoles destinados á la expedición contra Buenos Ayres. Ver Memoria Chilena, disponible en http://www.memoriachilena.cl/602/w3article-98631.html.

Vicuña Mackenna, Benjamín, Don Manuel Antonio Tocornal, reseña biográfica, Santiago de Chile, 1865, pp. 105-110, en Memoria Chilena, disponible en www. memoriachilena.cl/archivos2/pdfs/ MC0004535.pdf. 